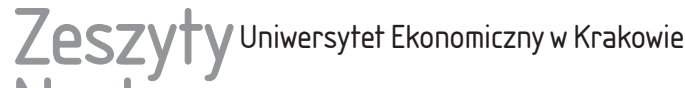 Naukowe
}

\section{Rachunki fizycznych przepływów wody jako element europejskich rachunków ekonomicznych środowiska}

\section{Streszczenie}

Woda jest kluczowym zasobem zapewniającym życie na ziemi. Uznawana jest dzisiaj za wyczerpywalny zasób odnawialny, dlatego konieczne jest gospodarowanie tym zasobem oraz regulowanie zasad korzystania z niego dla konkurujących użytkowników. Do zapewnienia zrównoważonego korzystania z zasobów wodnych niezbędne są rozbudowane narzędzia statystyczne dostarczające informacji dotyczących relacji między gospodarką a środowiskiem w zakresie wody. Podstawową kwestią jest oparcie ich na jednolitych definicjach i nomenklaturze rachunków narodowych.

Artykuł ma charakter przeglądowy i dotyczy tematyki rachunków środowiskowo-gospodarczych, które nie są jeszcze objęte obowiązkowymi wytycznymi UE. Prace nad metodologią tworzenia tych rachunków trwają na gruncie międzynarodowym, w tym w instytucjach Unii Europejskiej. Można się spodziewać, że znajdą się one w kolejnych modułach obowiązkowych rachunków środowiskowo-gospodarczych.

Słowa kluczowe: rachunki wody, rachunki fizycznych przepływów wody, europejski system rachunków środowiska, rachunki środowiskowo-gospodarcze dla wody.

Klasyfikacja JEL: Q56.

Ksymena Rosiek, Uniwersytet Ekonomiczny w Krakowie, Wydział Finansów i Prawa, Katedra Polityki Przemysłowej i Ekologicznej, ul. Rakowicka 27, 31-510 Kraków, e-mail: ksymena. rosiek@uek.krakow.pl 


\section{Wprowadzenie}

Zmiany klimatyczne oraz antropogeniczne prowadzą do rosnących problemów z zapewnieniem stabilności dostaw wody na potrzeby gospodarki narodowej, nawet w krajach wysoko rozwiniętych o odpowiedniej infrastrukturze gospodarki wodnej. Inwestycje związane zarówno z ochroną przeciwpowodziową, jak i zapewnieniem wody w okresach suszy są bardzo kosztowne, a ich podejmowanie powinno być ekonomicznie uzasadnione. W pierwszej kolejności należy wykorzystywać i wspierać naturalne procesy retencji, by następnie tam, gdzie to konieczne, sięgać po rozwiązania inżynieryjne. Konieczne jest bilansowanie zasobów wodnych w ramach zlewni oraz zarządzanie z uwzględnieniem potrzeb i priorytetów użytkowników wód w całej zlewni.

Pierwszym krokiem umożliwiającym takie działanie jest gromadzenie danych statystycznych dotyczących zasobów wodnych. Niestety okazuje się, że dane gromadzone współcześnie przez instytucje statystyczne i niektóre organizacje międzynarodowe nie są spójne, a podstawowe definicje różnią się pomiędzy krajami. Ponadto inne potrzeby informacyjne mają kraje ubogie w wodę i infrastrukturę wodną, a inne kraje wysoko rozwinięte (proporcjonalnie rachunki wody wprowadza dobrowolnie więcej krajów rozwijających się niż krajów rozwiniętych) (Rosiek 2015). Sytuacja komplikuje się, gdy konkurencja o ten ograniczony zasób przybiera formę międzypaństwowego konfliktu. Dotychczas wdrażanie rachunków było dobrowolne, ale wielu specjalistów spodziewa się, że będą one wskazane jako obowiązkowe w trzeciej turze rozbudowywania rachunków ekonomicznych środowiska w UE.

Zostały podjęte próby, aby oprócz istniejących statystyk środowiskowych stworzyć rachunki fizycznych przepływów wody powiązane z rachunkami narodowymi, co oznacza, że oparte są one na tej samej nomenklaturze. Dzięki temu możliwe będzie ujednolicenie sposobu gromadzenia i prezentowania danych, a jednocześnie podejmowanie bardziej skutecznych działań w celu zapewnienia wody na potrzeby gospodarki narodowej. Takie statystyki umożliwią również lepszą ochronę zasobów wodnych i ich utrzymanie w dobrym stanie w długim okresie.

Nowe statystyki mają lepiej odzwierciedlać czynniki wpływające na ilość i jakość wód, presję i skutki oddziaływania na zasoby wodne w czasie oraz mają być $\mathrm{w}$ większym stopniu powiązane z sektorami gospodarki.

Artykuł ma charakter przeglądowy i dotyczy tematyki rachunków ekonomicznych środowiska, które nie są objęte obowiązkowymi wytycznymi UE. 


\section{Europejskie i międzynarodowe wytyczne w zakresie rachunków wody}

Obecnie istnieje kilka instytucji gromadzących dane dotyczące zasobów wodnych i ich wykorzystania: OECD z Eurostatem, UNSD (z UNEP i FAO), WHO i UNICEF. Gromadzą one dane niezbędne do monitorowania realizacji wyznaczonych celów, np. WHO skupia się na danych związanych z ulepszonymi źródłami wody i sanitariatami. Większość gromadzonych danych pochodzących z poszczególnych państw powinna być spójna z systemem rachunków ekonomicznych środowiska dla wody (System of Environmental Economic Accounting for Water SEEA-Water). Istnieje jednak potrzeba połączenia tych informacji z danymi związanymi z produkcją przemysłową i dotyczącymi innych działów gospodarki. Obecnie wymaga to dodatkowych opracowań tematycznych. Większość krajów gromadzi informacje statystyczne o środowisku, ale szczegółowe analizy wskazują na istotne różnice nawet w podstawowych definicjach. Zaznaczyć należy, że nie ma jednolitych wytycznych nawet co do tak podstawowych definicji jak definicja wody słodkiej (freshwater). Według wymagań amerykańskich jest to taka woda, która zawiera mniej niż 1000 ppm soli, a według australijskich - jedynie 500 ppm (International Recommendations... 2010, s. 15). Poszczególne instytucje doprecyzowują definicje na własne potrzeby.

Głównym zadaniem systemu rachunków ekonomicznych środowiska jest lepsze odwzorowanie relacji pomiędzy gospodarką a środowiskiem, przepływów ze środowiska do gospodarki w ramach gospodarki (z uwzględnieniem strat) oraz z gospodarki do środowiska (z uwzględnieniem kryteriów jakości). Powinien on również uwzględniać zasady zintegrowanego zarządzania zasobami wodnymi.

Aby lepiej zrozumieć zasadę działania tych rachunków, należy wyjaśnić, że są one skonstruowane w taki sposób, żeby opisywać w jednostkach fizycznych zasoby środowiska i zmiany w nich oraz alokację tych zasobów z uwzględnieniem różnych aktywności gospodarczych. Alokacje te są rejestrowane w tabelach podaży i wykorzystania (phisical supply and use tables - PSUT), co właśnie definiuje rachunki przepływów fizycznych zasobów (Barbier i Markandya 2013, s. 83).

$\mathrm{W}$ ramach tych rachunków gromadzone i integrowane są informacje $\mathrm{z}$ różnych działów i dziedzin statystyki, dając spójny pakiet informacji, na podstawie których można tworzyć wskaźniki zrozumiałe dla interesariuszy. O ile same rachunki są przedmiotem zainteresowań specjalistów i naukowców, o tyle tworzone na ich podstawie indeksy mają być zrozumiałe dla polityków oraz społeczeństwa i ułatwiać opis zmian zachodzących w gospodarkach poszczególnych krajów, ich presji na środowisko oraz zmian pozytywnych. Rachunki ekonomiczne środowiska są rachunkami satelitarnymi wobec rachunków narodowych, a więc oparte są na ich nomenklaturze. Podstawową różnicą jest to, że każde oddziaływanie powinno 
być powiązane z rezydentem, jest więc rejestrowane według miejsca rejestracji rezydenta, a nie faktycznego wystąpienia oddziaływania. Powstałe wskaźniki mogą dać odpowiedź na pytanie, jaki wpływ w skali świata mają poszczególne kraje, ale w niektórych przypadkach (zwłaszcza jeśli chodzi o emisję do powietrza) mogą się znacząco różnić od statystyki środowiskowej rejestrującej oddziaływania według miejsca ich wystąpienia. W przypadku wody dane gromadzone są według zlewni, a nie podziału jednostek terytorialnych dla celów statystycznych (NUTS). Rachunki te mają umożliwiać nie tylko łączenie danych gospodarczych ze środowiskowymi, ale również szacowanie przyszłych trendów. Będą więc użytecznym narzędziem polityki gospodarczej.

Rachunki te są inicjatywą międzynarodową. Proces ich powstawania jest koordynowany przez UNDS (United Nations Statistics Division), ale ważny wkład w budowanie metodologii miały London Group on Environmental Accounting ${ }^{1}$, Eurostat i inne instytucje statystyczne. Pierwsze wytyczne zostały opublikowane w 2003 r., gdy powstała podgrupa ds. rachunków wody, ale prace trwały nadal, a wytyczne zostały ostatecznie opublikowane w 2012 r. ${ }^{2}$ (System... 2012, s. 5). Należy jeszcze wspomnieć, że wytyczne te są zgodne z International Recommendations for Water Statistics ${ }^{3}$ (2010), których celem było wzmocnienie krajowych systemów gromadzenia danych dotyczących wody.

Unia Europejska przez Eurostat i inne agencje, np. Europejską Agencję Środowiska (EEA), aktywnie uczestniczyła w kształtowaniu rachunków ekonomicznych środowiska. Pierwsze obowiązkowe wytyczne zostały opublikowane w $2011 \mathrm{r}$. (Rozporządzenie Parlamentu Europejskiego i Rady (UE) nr 691/2011...), a kolejne rozporządzenia wprowadzały po trzy kolejne moduły w latach 2013 i 2014 (Rozporządzenie Parlamentu Europejskiego i Rady (UE) nr 99/2013..., Rozporządzenie Parlamentu Europejskiego i Rady (UE) nr 538/2014...). Szacuje się, że właśnie rachunki wody staną się jednym z kolejnych obowiązkowych rachunków, gdyż zapisy o ich ważności znajdują się w siódmym unijnym planie działań na rzecz środowiska (Decyzja Parlamentu Europejskiego i Rady nr 1386/2013/UE..., akap. 42) oraz w Europejskiej strategii rozwoju rachunków środowiskowych na lata 2014-2018 (European Strategy... 2014, s. 4), choć zapisano w tym dokumencie, że należy rozwijać dobrowolne gromadzenie danych w zakresie wody. Można się

1 Jest to nieformalna grupa współpracujących systematycznie specjalistów, głównie z narodowych biur statystycznych oraz przedstawicieli organizacji pozarządowych. Powstała w $1993 \mathrm{r}$. Szerzej zob.: https://unstats.un.org/unsd/envaccounting/londongroup (data dostępu: 30.08.2017).

2 Wcześniej publikowane były liczne tymczasowe wytyczne, raporty z pilotażowych badań, które były tematem dyskusji, w tym internetowych konsultacji.

${ }^{3}$ Różnica pomiędzy IRWS a SEEA-Water polega na tym, że te pierwsze nie obejmują wielu danych łączących aspekty społeczne i korzystania z wody oraz niektórych danych dotyczących jakości wody oraz praw własności (International Recommendations... 2010, ust 1.4-1.6) 
jednak spodziewać, że jest to przygotowanie do wprowadzenia obowiązkowych rozwiązań w kolejnym okresie. Natomiast w Europejskim programie statystycznym jest zapis o konieczności rozwoju m.in. rachunków wody (Rozporządzenie Parlamentu Europejskiego i Rady (UE) nr 99/2013..., Aneks, cel 2.2.1). Aktualne wytyczne dotyczące rachunków fizycznych przepływów wody (physical water flow accounts) zostały opublikowane w 2014 r. (Physical Water... 2014).

Jak widać, rozwój rachunków ekonomicznych środowiska jest silnie zakorzeniony w wytycznych unijnych i międzynarodowych, co w istotny sposób wspiera ich rozwój. Ważne jest jednak, żeby z dobrowolnych modułów stawały się one obowiązkowymi, co będzie gwarantowało jakość, spójność i aktualność danych.

\section{Rachunki fizycznych przepływów wody - struktura i wymagania}

Woda jest zasobem, który jest niezbędny do podtrzymania życia na ziemi i wielu różnych interesariuszy konkuruje o dostęp do niej. W skali świata największymi „konkurentami” są przemysł wraz z energetyką oraz rolnictwo. Z perspektywy społecznej istotne są kwestie dostępu do wody pitnej dla ludności, a z perspektywy środowiska - utrzymanie i zabezpieczenie odpowiedniej ilości i jakości zasobów wodnych oraz ekosystemów. Statystyki wodne powinny więc kompleksowo odpowiadać na to zapotrzebowanie informacyjne, aby można było opisać i badać ważne zależności, zarówno jeśli chodzi o presję na zasoby, jak i kwestie społeczne. PWFA są budowane na podstawie wspomnianych międzynarodowych standardów SEEA-Water oraz IRWS. Rachunki te mają umożliwić szczegółową rejestrację przepływów wody między środowiskiem a gospodarką (wkład natury - natural inputs), tego, co się dzieje w gospodarce (podaż i wykorzystanie zasobów przez przemysł i gospodarstwa domowe), oraz przepływów między gospodarką a środowiskiem (w tym water residuals), jak również ewidencjonowanie emisji do wód (pollutants), wszystko zgodnie z nomenklaturą rachunków narodowych (SNA i ESA). PWFA rejestrują bowiem przepływy wody w powiązaniu z działalnością gospodarczą rezydentów (podmiotów gospodarki narodowej) w kategoriach produkcji, konsumpcji i akumulacji. Pomijane są natomiast przepływy w środowisku.

W praktyce PWFA stanowi pięć tabel: dwie tabele podaży i wykorzystania dotyczące wody, dwie tabele podaży i wykorzystania dotyczące emisji (w jednostkach fizycznych) oraz jedna tabela podsumowująca i łącząca informacje, umożliwiająca generowanie kluczowych wskaźników dotyczących wody. Większość danych będzie mogła być pozyskana ze statystyki wodnej (OECD/Eurostat Joint Questionnaire on Inland Waters), ale ich układ pozwoli lepiej powiązać je z funkcjonowaniem gospodarki (Physical Water... 2014, s. 5-7). 
We wszystkich rachunkach przepływów fizycznych tworzonych w ramach SEEA obowiązują te same ramy definicyjne (np. w ogólnogospodarczych rachunkach przepływów materialnych czy w rachunkach fizycznych przepływów energii). Podstawowe są trzy przepływy:

- wkład natury (natural inputs),

- produkty (products),

- odpady/pozostałości (residuals ${ }^{4}$.

Wkład natury jest definiowany jako zasób, który jest pobierany ze środowiska do wykorzystania w procesie produkcyjnym (woda, surowce) lub wykorzystywany wprost $\mathrm{w}$ produkcji (powietrze do spalania, surowce mineralne w glebie do produkcji roślinnej).

Produkty definiowane są jako produkty i usługi powstałe jako efekt procesu produkcji w gospodarce; zgodnie z zasadami SNA są one rejestrowane jako przepływy finansowe między podmiotami gospodarki narodowej. W przypadku rachunków przepływów fizycznych znajdują się tu jednak pewne przepływy wewnętrzne w podmiotach, nierejestrowane przez rynek w postaci transakcji. Ma to również znaczenie w przypadku szacowania konsumpcji w gospodarstwach domowych.

Odpady/pozostałości (residuals) to wprowadzane do środowiska ciała stałe, płyny, gazy, minerały i energia, które są emitowane przez przedsiębiorstwa i gospodarstwa domowe w procesie produkcji, konsumpcji lub akumulacji, ale mogą też przepływać w gospodarce. W tabelach pojawia się również kategoria odpadów z zasobów naturalnych (natural resources residuals). Jest to kategoria istotna sama w sobie, ale jej nazwa jest niejednoznaczna zarówno w języku polskim, jak i angielskim. Chodzi mianowicie o tę część zasobów, która została pozyskana ze środowiska, ale nie została wykorzystana w procesie produkcji i zazwyczaj wraca do środowiska od razu, ale sam fakt wydobycia wpływa na ten zasób (straty, niewykorzystane zasoby). W przypadku wody będą to np. wody kopalniane. W sytuacji gdy odpad z zasobów naturalnych zostanie sprzedany, musi być już jednak ujmowany jako wydobycie wykorzystane w produkcji.

Zaznaczyć również trzeba, że z faktu, że są to rachunki oparte na nomenklaturze rachunków narodowych, wynika kilka istotnych kwestii. Po pierwsze rejestrowane są przepływy wody związane z rezydentami, a nie z aktywnością podmiotów na terenie kraju. Oznacza to, że przepływy wody związane z zagraniczną działalnością rezydentów muszą być ujmowane w rachunkach, a z drugiej strony odejmuje się te przypisywane zagranicznym rezydentom. Dlatego również nie są ujmowane przepływy wewnętrzne w środowisku. W rachunkach przepływów fizycznych reje-

${ }^{4}$ Termin residuals jest różnie tłumaczony; czasami jako odpady lub zanieczyszczenia (literalnie: resztki), czasami wskazuje się jednak, że jest to ta część odpadów, która może i powinna być wykorzystana. 
strowane są również wszystkie przepływy wewnętrzne, produkcja i wykorzystanie na własny użytek, podczas gdy w NSA tylko produkcja końcowa na własny użytek. W przypadku wody jest to istotne, bo mówimy tu np. o poborze wody gruntowej na własny użytek, jeżeli nie jest to działalność podstawowa. Takich szczegółowych różnic jest wiele i trudno je omówić w jednym artykule.

Podstawowy schemat jest oparty na dwóch typach tabel, tabeli podaży oraz tabeli wykorzystania, które mają taką samą strukturę. W wierszach ujęte są przepływy fizyczne (wkład, produkty, odpady), a w kolumnach źródła i kierunki wykorzystania wspomnianych przepływów przez przemysł i gospodarstwa domowe oraz akumulacja (jako zmiana ilości produktów i zapasów). Dodane są również kolumny: reszta świata (zagranica) - rejestrujące import i eksport, oraz środowisko - jako dostarczyciel i odbiorca zasobów. Tabela podaży rejestruje więc przepływy według kierunków pochodzenia, a tabela wykorzystania według kierunków przeznaczenia (docelowego wykorzystania). Każdy przepływ jest rejestrowany w obu tabelach.

Każda poszczególna komórka w tabeli jest efektem zsumowania danych z szczegółowych podtabel. Wszystkie gromadzone dane są zgodne z układami ISIC (International Standard Industrial Classifcation of All Economic Activities) i NACE (Statystyczna Klasyfikacja Działalności Gospodarczej we Wspólnocie Europejskiej). Układów tych jest pięć (wszystkie w jednostkach fizycznych) (Physical Water... 2014, s. 15):

- Table A - tabela podaży wody (physical water supply table),

- Table $B$ - tabela wykorzystania wody (physical water use table),

- Table $C$ - tabela podaży emisji do wody (physical supply table for emissions to water),

- Table D - tabela wykorzystania emisji do wody (physical use table for emissions to water),

- Table E- kluczowe wskaźniki (key water indicators).

Istotne jest również to, co jest uważane za produkty. Klasyfikuje się je według kategorii zgodnych z CPA (Statistical Classification of Products by Activity in the European Economic Community).

Wody pobierane ze środowiska klasyfikowane są według pochodzenia, a odprowadzane ścieki i wody odpadowe są rejestrowane według kryterium jakości.

Strukturę tabel podaży i wykorzystania dla rachunków wody prezentuje tabela 1.

Jak już wspomniano, głównym celem rozbudowy rachunków satelitarnych środowiskowo-gospodarczych (rachunki ekonomiczne środowiska - SEEA), w tym rachunków wody, jest możliwość generowania wskaźników użytecznych w monitorowaniu relacji miedzy środowiskiem a gospodarką. Zestaw takich wskaźników zaprezentowano w tabeli 2. 


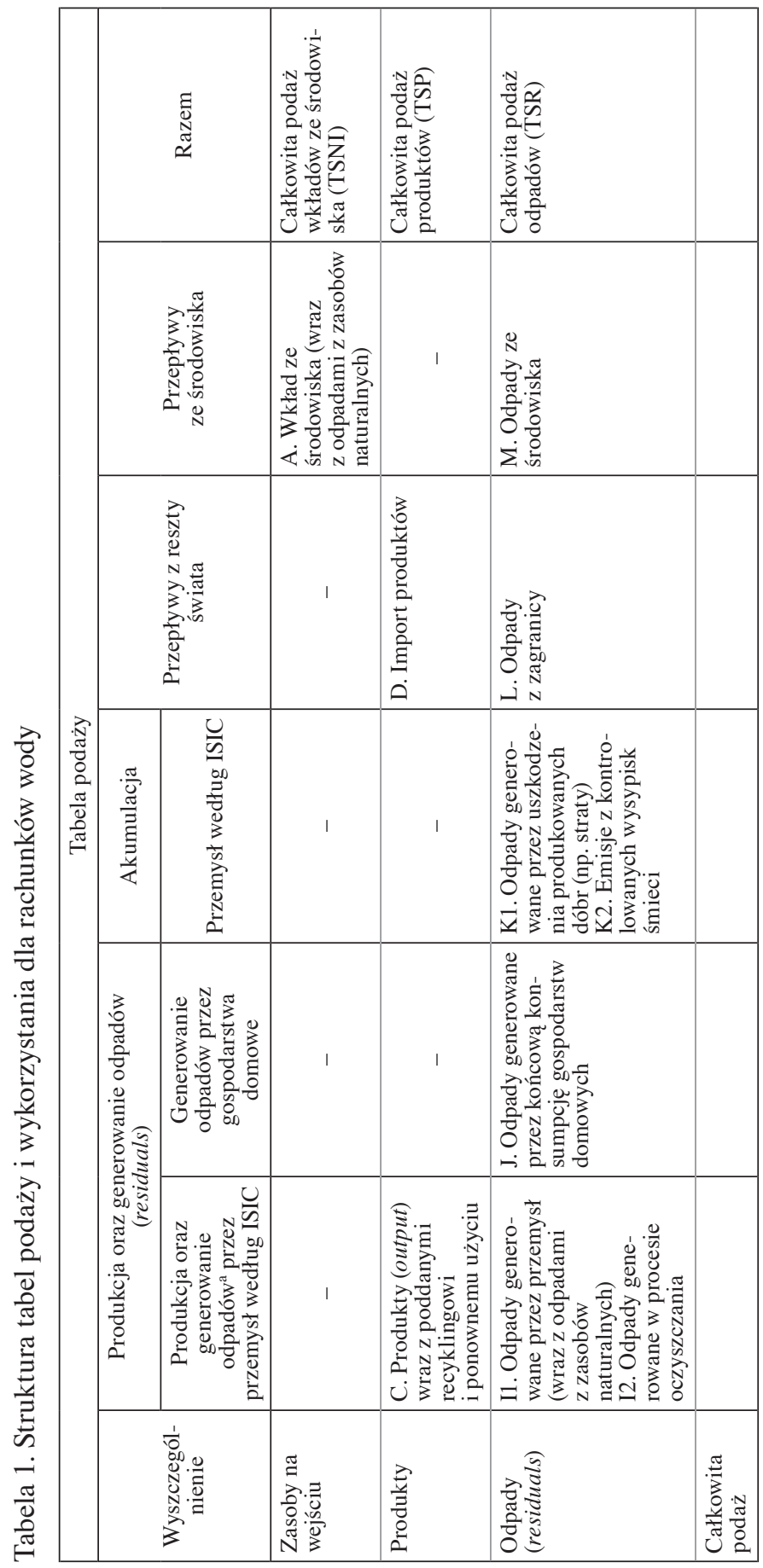




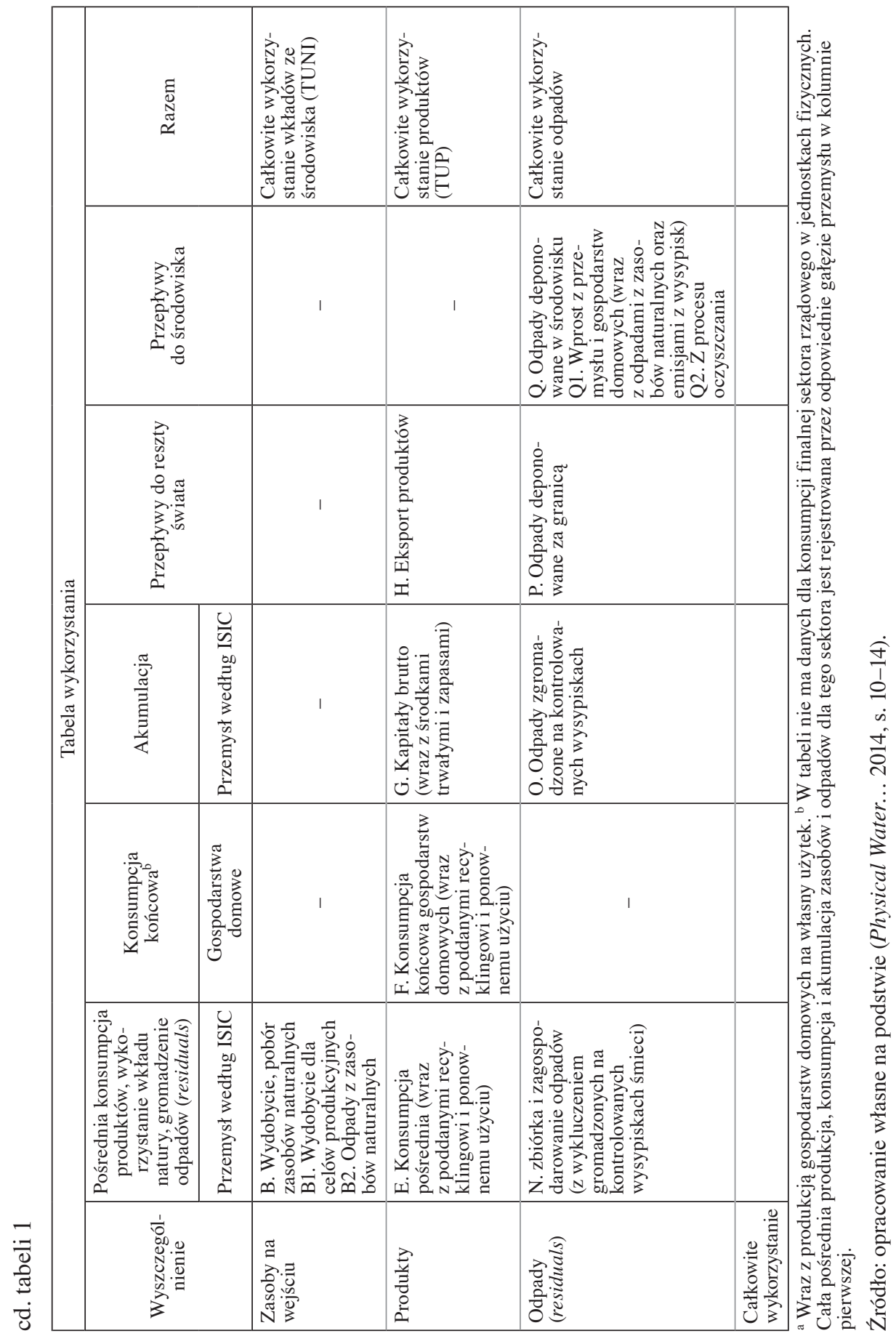


Tabela 2. Kluczowe wskaźniki dla wody

\begin{tabular}{|c|c|c|}
\hline \multirow{2}{*}{ Kod } & \multicolumn{2}{|c|}{ Nazwa wskaźnika i jednostka } \\
\hline & w języku angielskim & w języku polskim \\
\hline K.1 & Water consumption $\left(\mathrm{m}^{3}\right)$ & Konsumpcja wody $\left(\mathrm{m}^{3}\right)$ \\
\hline K.2 & $\begin{array}{l}\text { Water consumption per GVA (gross value } \\
\text { added) ( } \mathrm{m}^{3} \text { per currency unit) }\end{array}$ & $\begin{array}{l}\text { Konsumpcja wody na wartość dodaną } \\
\text { brutto }\left(\mathrm{m}^{3} \text { na jednostkę pieniężną) }\right.\end{array}$ \\
\hline K.3 & $\begin{array}{l}\text { Water consumption per production output } \\
\text { ( } \mathrm{m}^{3} \text { per currency unit) }\end{array}$ & $\begin{array}{l}\text { Konsumpcja wody na wartość dodaną } \\
\text { brutto }\left(\mathrm{m}^{3} \text { na jednostkę pieniężną) }\right.\end{array}$ \\
\hline K.4 & Water use $\left(\mathrm{m}^{3}\right)$ & Wykorzystanie wody $\left(\mathrm{m}^{3}\right)$ \\
\hline K.4.1 & $\begin{array}{l}\text { - of which: natural inputs (i.e. direct } \\
\text { abstraction) }\left(\mathrm{m}^{3} \text { and /or \%) }\right.\end{array}$ & - w tym: wkład z natury $\left(\mathrm{m}^{3}\right.$ lub $\left.\%\right)$ \\
\hline K.4.1.1 & $\begin{array}{l}\text { - of which from surface and groundwater } \\
\left(\mathrm{m}^{3} \text { and } / \text { or } \%\right)\end{array}$ & $\begin{array}{l}\text { - w tym: wody powierzchniowe } \\
\text { i gruntowe }\left(\mathrm{m}^{3} \text { lub \%) }\right.\end{array}$ \\
\hline K.5 & $\begin{array}{l}\text { Water use per GVA (gross value added) } \\
\left(\mathrm{m}^{3} \text { per currency unit) }\right.\end{array}$ & $\begin{array}{l}\text { Wykorzystanie wody na wartość dodaną } \\
\text { brutto }\left(\mathrm{m}^{3} \text { na jednostkę pieniężną) }\right.\end{array}$ \\
\hline K.6 & $\begin{array}{l}\text { Water use per production output }\left(\mathrm{m}^{3} \text { per }\right. \\
\text { currency unit) }\end{array}$ & $\begin{array}{l}\text { Wykorzystanie wody na jednostkę produk- } \\
\text { cji }\left(\mathrm{m}^{3} \text { na jednostkę pieniężną) }\right.\end{array}$ \\
\hline K.7 & Water consumption/water use & Konsumpcja wody/wykorzystanie wody \\
\hline K.8 & Losses in distribution/total water use & $\begin{array}{l}\text { Straty w dystrybucji/całkowitego wyko- } \\
\text { rzystania wody }\end{array}$ \\
\hline K.9 & Net Emissions (kg) & Emisje netto $(\mathrm{kg})$ \\
\hline K.10 & $\begin{array}{l}\text { Net Emissions per GVA (kg per currency } \\
\text { unit) }\end{array}$ & $\begin{array}{l}\text { Emisje netto na wartość dodaną brutto } \\
\text { (kg na jednostkę pieniężną) }\end{array}$ \\
\hline K.11 & $\begin{array}{l}\text { Net Emissions per Production Output } \\
\text { (kg per currency unit) }\end{array}$ & $\begin{array}{l}\text { Emisje netto na jednostkę produkcji } \\
\text { (kg na jednostkę pieniężną) }\end{array}$ \\
\hline
\end{tabular}

Źródło: opracowanie własne na podstawie (Physical Water... 2014, s. 29-30).

Dzięki gromadzeniu danych według zasad rachunków ekonomicznych środowiska możliwe jest połączenie danych o gospodarce oraz danych o oddziaływaniu procesów gospodarczych na środowisko i wygenerowanie użytecznych dla interesariuszy wskaźników informujących o tych relacjach. O ile same rachunki ekonomiczne środowiska pozostaną zapewne domeną naukowców i specjalistów z zakresu statystyki narodowej, to wskaźniki powstające dzięki gromadzonym danym będą miały szersze zastosowanie.

\section{Podsumowanie}

Rachunki fizycznych przepływów wody mają dzięki oparciu ich na nomenklaturze rachunków narodowych łączyć dane o eksploatacji zasobów wodnych ze 
środowiska i ich przepływach w gospodarce oraz presji wywieranej na środowisko. Dzięki temu można będzie tworzyć wskaźniki odnoszące wielkości wykorzystywanych zasobów do kategorii ekonomicznych. Rachunki ekonomiczne środowiska przewidują jednak dalszą ich rozbudowę. Stworzenie spójnych rachunków fizycznych przepływów zasobów (energii, wody i niektórych innych zasobów) jest bowiem pierwszym krokiem do tworzenia rachunków hybrydowych fizyczno-monetarnych. SEEA przewiduje takie rachunki jako kolejny moduł (System... 2012, s. 9-13). Problem stanowi oczywiście cena, która nie odpowiada wartości wykorzystywanych zasobów wodnych. Rozwój metod wyceny walorów środowiska i usług ekosystemów stanowić będzie o możliwości tworzenia takich rachunków. Uznać jednak należy, że nigdy nie będzie można w pełni odzwierciedlić w rachunkach ekonomicznych pełnej wartości dóbr i usług środowiskowych, choćby dlatego że zmienia się ona dynamicznie w czasie.

Niemniej jednak wydaje się, że praca wielu zespołów na całym świecie przynieść może wymierne korzyści w postaci lepszej bazy informacyjnej. Niepokojące jest natomiast to, że w publikowanych już danych i wskaźnikach (z tego czy wcześniejszych modułów) nie ma żadnego wyraźnego oznaczenia, że pochodzą one ze statystyki rachunków satelitarnych. Mniej doświadczony użytkownik znajdzie więc w bazach Eurostatu grupy wskaźników lub danych pochodzących ze statystyki środowiskowej i ze statystyki rachunków satelitarnych ${ }^{5}$. Będą się one od siebie różnić, a wyjaśnienie tych różnic nie będzie intuicyjne.

\section{Literatura}

Barbier E.B., Markandya A. (2013), A New Blueprint for a Green Economy, Routledge, New York.

Decyzja Parlamentu Europejskiego i Rady nr 1386/2013/UE z dnia 20 listopada 2013 r. w sprawie ogólnego unijnego programu działań w zakresie środowiska do $2020 \mathrm{r}$. „Dobra jakość życia z uwzględnieniem ograniczeń naszej planety”, Dz. Urz. UE L 354/171 z 28.12.2013.

European Strategy for Environmental Accounts (2014), ESSC 2014/21/24/EN, http:// ec.europa.eu/eurostat/documents/1798247/6079569/ESSC-2014-21-EN-24-EuropeanStrategy-env.pdf (data dostępu: 16.02.2017).

International Recommendations for Water Statistics (2010), United Nations, https://unstats. un.org/unsd/envaccounting/irws (data dostępu: 26.10.2016).

Physical Water Flow Accounts (PWFA). Manual ver. 2014 (2014), Eurostat, http:// ec.europa.eu/eurostat/dokuments/1798247/6664269/Manual+for+Physical+Water+ Flow+Accounts+\%28draft+version+18+Nov+2014\%29.pdf (data dostępu: 29.08.2017).

5 Od początku 2018 r. rachunki emisji z rachunków ekonomicznych środowiska w Eurostacie są oznaczane dodatkowym symbolem SEEA, co nie zmienia faktu, że dla większości użytkowników tych serwisów statystycznych będzie to nadal mało czytelne. 
Rosiek K. (2015), Rachunki gospodarczo-środowiskowe - przeglq̨d międzynarodowy, „Ekonomia i Środowisko”, nr 4(55).

Rozporządzenie Parlamentu Europejskiego i Rady (UE) nr 99/2013 z dnia 15 stycznia 2013 r. w sprawie Europejskiego programu statystycznego 2013-2017, Dz. Urz. L 39 z 9.02.2013.

Rozporządzenie Parlamentu Europejskiego i Rady (UE) nr 538/2014 z dnia 16 kwietnia 2014 r. zmieniające rozporządzenie (UE) nr 691/2011 w sprawie europejskich rachunków ekonomicznych środowiska, Dz. Urz. UE L 158 z 27.05.2014.

Rozporządzenie Parlamentu Europejskiego i Rady (UE) nr 691/2011 z dnia 6 lipca 2011 r. w sprawie europejskich rachunków ekonomicznych środowiska, Dz. Urz. UE. L 192 z 22.07.2011.

System of Environmental-Economic Accounting for Water (2012), United Nations, https:// unstats.un.org/unsd/envaccounting/seeaw/seeawaterwebversion.pdf (data dostępu: 26.10.2016).

\section{Physical Water Flow Accounts as a Part of European Environmental Economic Accounting}

(Abstract)

Water is a crucial resource that ensures life on the planet. It is defined as a replenishable but depletable resource, so it is necessary to manage it and define the rules and boundaries of its usage among competing users. To ensure sustainable water resource use, it is necessary to create sophisticated statistical tools that can provide information about the relations between economy and the environment. Basing them on coherent definitions and the national accounts nomenclature is of utmost importance.

This article concerns aspects of economic environmental accounting that are still not obligatory in the EU, though they are practiced, and intensively so, both in the EU and further afield. It can be expected that they will be included in the next obligatory modules of ESEA, which are to be introduced soon.

Keywords: water accounts, physical water flow accounts (PWFA), European System of Environmental Accounts (ESEA), System of Environmental and Economic Accounting for Water (SEEA-Water). 